\title{
OBSERVATIONS ON THE OPISTHOBRANCH MOLLUSC ACTEON TORNATILIS (L.).
}

\author{
By Vera Fretter, D.Sc. \\ Department of Zoology, Birkbeck College, University of London \\ and Alastair Graham, D.Sc. \\ Department of Zoology, University of Reading \\ (Text-figs. I-9)

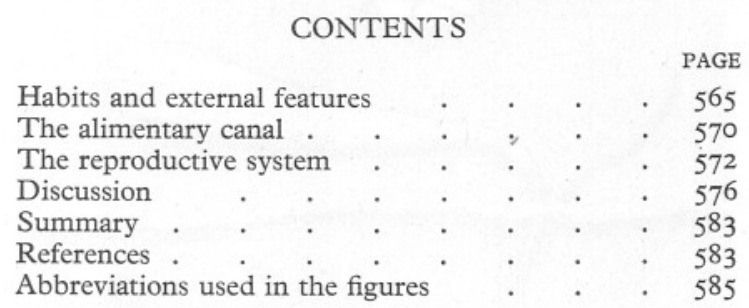

Habits and External Features

Acteon tornatilis (L.), the most primitive British opisthobranch, may be collected in large numbers at Pendine Sands, Carmarthenshire, where, during early September, occasional individuals may be seen creeping over the shore near the water's edge at low tide. More conspicuous than the adult animals, however, at that time of the year are the gelatinous masses of spawn: these measure about $6 \mathrm{~cm}$ in length, are club-shaped and taper towards one end which is secured to a piece of weed, wood or stone, usually on the surface of the sand but often underneath. Sometimes molluscs are found with the egg mass trailing from the genital aperture: if these are followed they may be seen, when near an object projecting from the sand, to burrow a short distance, and, whilst the mollusc is out of sight, the last secretions are poured from the female opening and the mass fastened to the buried object, presumably by means of the foot.

During the ebb tide most of the specimens of Acteon which live in the area are not on the surface of the sand because they then tunnel through the upper $6 \mathrm{in}$. Their burrows open to the surface by a hole $4-5 \mathrm{~mm}$ in diameter, and, once this is realized, it is an easy matter to collect them. The method of burrowing may be followed in the laboratory. An individual placed on sand will creep over the surface leaving behind it a characteristic trail which is formed by the head lobes (i.e. expanded and flattened cephalic and labial tentacles) and by the widely expanded foot, the former lying in front of the 
latter (see Fig. I). These structures act like a snow-plough, pushing aside the sand and heaping it on either side of the path; strong ciliary currents beat towards the free edges of the head and posteriorly over the sole of the foot to keep these surfaces clean, and the tentacles are reflexed over the edge of the shell so as to close off the mantle cavity. After creeping for a short distance over the surface the mollusc soon presses deeper into the sand and disappears from sight, the sand closing over behind it. What happens then may be seen if

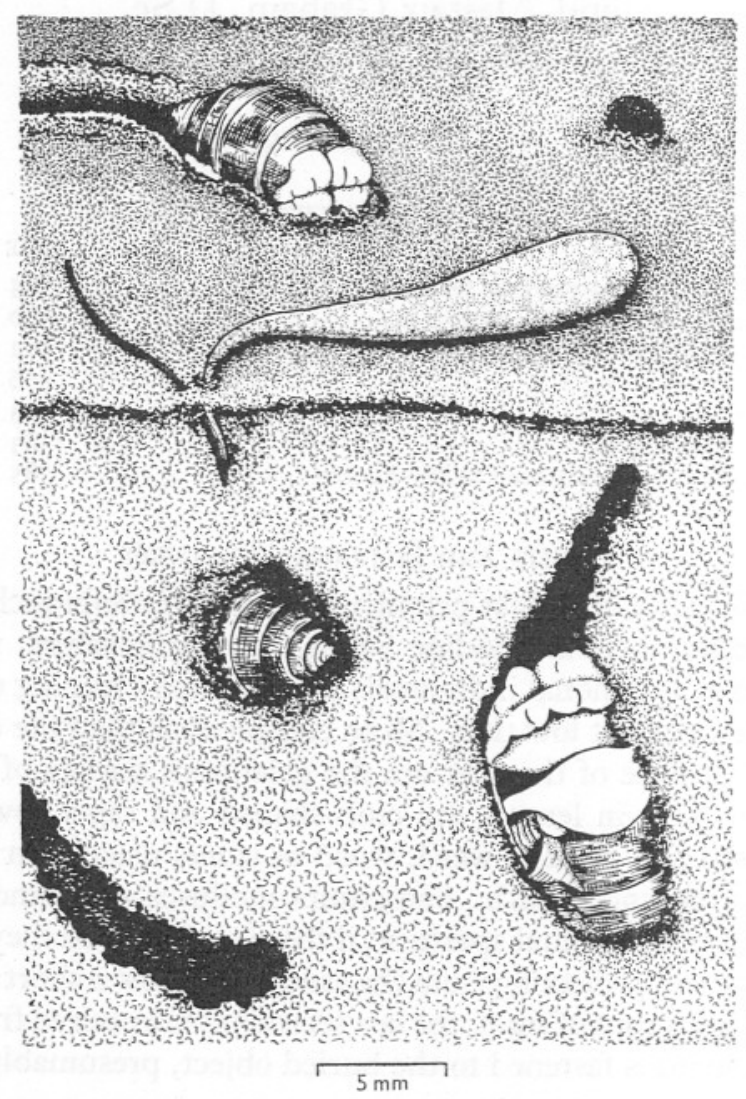

Fig. I. A. tornatilis in its natural habitat. In the upper part of the drawing an animal is seen creeping over the surface of the sand, and the opening of a burrow is in the top right-hand corner. In the middle a mass of spawn lies on the surface attached to weed a little below. In the lower half of the drawing a mollusc is shown in its burrow. The exhalant siphon shows on its left.

a tunnel be made against the side of an aquarium. The mollusc will travel vertically or diagonally downwards for an inch or two, then horizontally, and, sooner or later, will start towards the surface again. Its progress is slow. As it moves the burrow does not collapse behind it, for secretion from the head 
lobes and pedal gland is pressed against the sand and agglutinates the particles. On reaching the surface the head is pressed back against the rim of the opening to make the edges firm with secretion and the animal may remain in this position for some time. Alternatively it may retreat, moving backwards as it goes, so that the head is kept facing the mouth of the burrow, and it may come to rest a few inches down with the semi-contracted foot holding firmly. The right margin of the foot overhangs the conspicuous exhalant siphon, which is partially protected, too, by the edges of the shell, and a slow, continuous current of water, apparently free from sand particles, passes out of the siphon. When the animal emerges fully from its shell this exhalant siphon comes to occupy the posterior corner of the mouth of the shell.

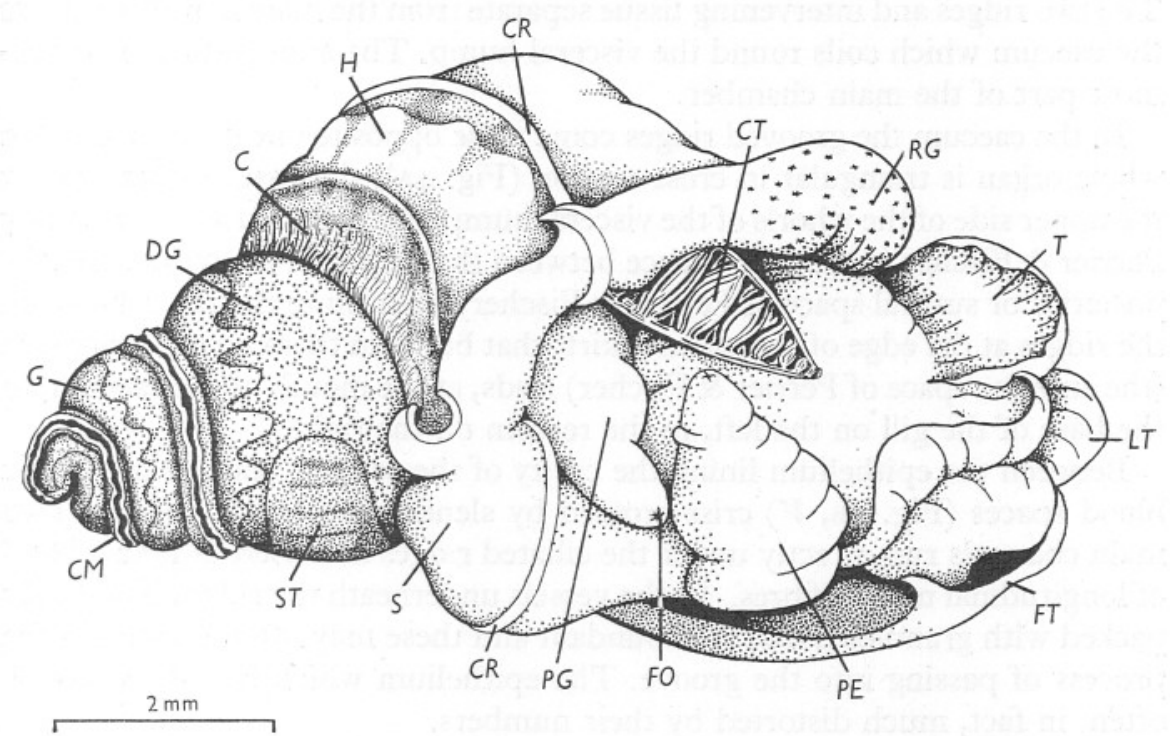

Fig. 2. A. tornatilis with shell removed. For explanation of lettering see p. 585 .

Some of the primitive features of Acteon may be correlated with the large size of the shell, which permits the animal to withdraw completely and seal itself with an operculum. The body whorl is deep, its aperture an elongated slit along the right side with a length equal to about two thirds the height of the shell. This may be correlated with the fact that the mantle cavity of Acteon is at least as large as in any other opisthobranch and resembles that of a prosobranch in having to accommodate such structures as a large penis (Fig. 2, $P E$ ) which cannot be invaginated, and pallial genital ducts $(P G)$ which in many gastropods have sunk into the haemocoel. The shape of the cavity differs from that of the typical prosobranch in two important respects: the opening, though large and anterior, is markedly twisted to the right so that there is no opening left of the mid-line, where the gill is attached; and the cavity is drawn out 
posteriorly into a narrow extension $(C M)$ which runs separately alongside the main spiral of the visceral hump almost or quite to its apex.

The posterior extension of the mantle cavity lies right of the gill, but left of the rectum and genital tract, and is, therefore, a derivative of the hypobranchial region. Along it run two grooved and ciliated ridges $(C R)$, both of which lead to the free edge of the mantle skirt anteriorly. The grooves were not described by previous workers. The left of these, the larger of the two, lies parallel to the ctenidium and is placed just right of the mid-line; the right lies left of the rectum and leads on to the expanded flap of pallial tissue used as an exhalant siphon $(S)$. Glandular tissue intermixed with ciliated cells lines the wall along and between these ridges and represents the hypobranchial gland. The two ridges and intervening tissue separate from the main mantle cavity as the caecum which coils round the visceral hump. The anus lies in the innermost part of the main chamber.

In the caecum the grooved ridges come to lie opposite one another and the whole organ is triangular in cross-section (Fig. 4A), the base resting against the upper side of the whorls of the visceral hump, not flattened as described by Perrier \& Fischer (I9II). The space between the ridges on the outer side (the posterior or sutural space of Perrier \& Fischer) leads on to the space between the ridges at the edge of the mantle skirt; that between them on the inner side (the anterior space of Perrier \& Fischer) leads, at the mouth of the caecum, to the base of the gill on the left, to the rectum on the right.

Between the epithelium lining the cavity of the caecum and the mantle lie blood spaces (Fig. 4B, $V$ ) criss-crossed by slender strands of muscle. Two main channels run directly under the ciliated ridges and there is here a band of longitudinal muscle fibres. In the vessels underneath the ridges blood cells packed with granules $(A M)$ are abundant and these may often be seen in the process of passing into the groove. The epithelium which lies at its base is often, in fact, much distorted by their numbers.

The glands of the caecum are of two sorts, one a 'mucous' cell $(M C)$, secreting mucoitin sulphuric acid, the other $(G C)$ producing granules of a substance staining intensely with iron haematoxylin. Both are of types commonly encountered in the hypobranchial gland of other gastropods.

Ciliary currents (Fig. 3) run across the ridges into the posterior space of the caecum, where they set in an outward direction so that particulate matter (including extruded blood cells) is swept to the region of the exhalant siphonal fold on to which currents from the anus and surrounding parts also converge. A compensating ingoing current travels up the anterior space of the caecum so that a circulation of water is maintained.

The edge of the mantle skirt in Acteon, in its left half, is greatly thickened by the presence of elaborate glands called by Pelseneer (I894) the semilunar gland. These form a belt, parallel to the edge, which has a pitted aspect, each depression being the mouth of a compound tubular or flask-shaped gland. If 


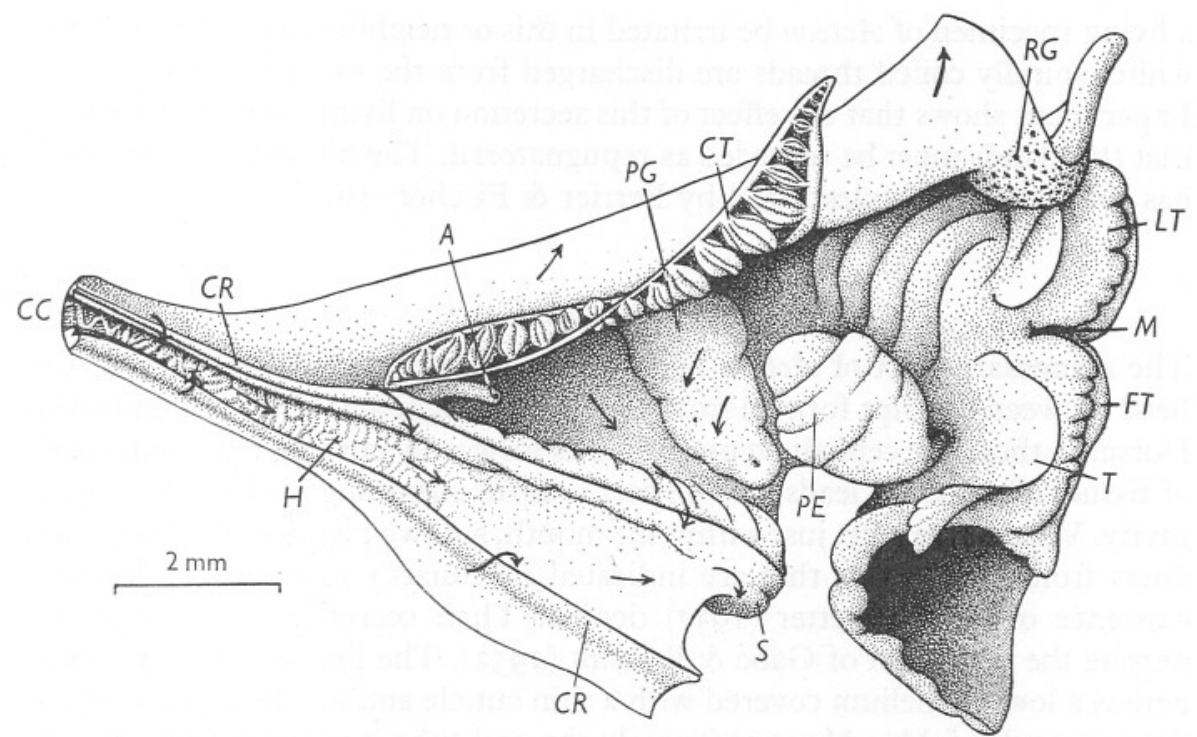

Fig. 3. A. tornatilis. Mantle cavity and base of caecum opened by a longitudinal slit to the right of the ctenidial axis. Arrows show direction of ciliary currents. For explanation of lettering see p. 585 .
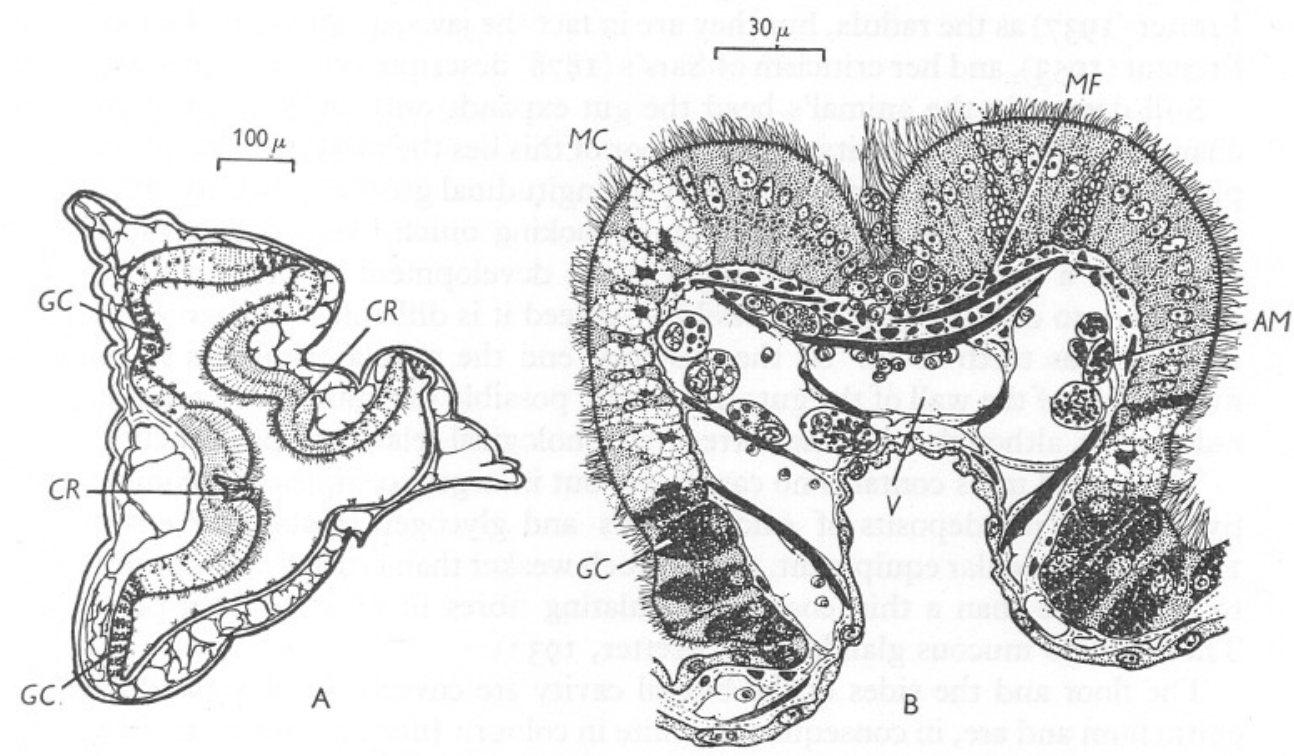

Fig. 4. A. tornatilis. A: transverse section of the caecum; B, transverse section of ciliated ridge of the caecum. For explanation of lettering see p. 585 . 
a living specimen of Acteon be irritated in this or neighbouring regions small, white, spirally coiled threads are discharged from the mouths of the glands. Experiment shows that the effect of this secretion on living animals is toxic so that the glands must be regarded as repugnatorial. The histology of the gland has been adequately described by Perrier \& Fischer (I9II).

\section{The Alimentary Canal}

The alimentary tract of Acteon opens at the mouth placed anteriorly on the head between two lips formed from the bases of right and left labial tentacles. Dorsal to these the cephalic tentacles lie as forwardly curving flattened sheets of tissue. The mouth leads into a short oral tube running back to the buccal cavity. Ventro-laterally, just within the mouth, are two papillae on which open ducts from oral glands that are indicated in Guiart's plate (I90I), but the existence of which Fretter (1937) denied. Their secretion is not mucous, despite the allegation of Gabe \& Prenant (1952). The lining of the oral tube here is a low epithelium covered with a thin cuticle and it is flung into two or three irregular folds. More posteriorly the oral tube is narrowed to a dorsoventral slit passing between two bulges, one in each lateral wall. These are muscular and the epithelium over them bears a cuticle made of small oval plates each with a denticulate edge. These are the structures described by Fretter (1937) as the radula, but they are in fact the jaws, as shown by Gabe \& Prenant (1953), and her criticism of Sars's (1878) description is not warranted.

Still deeper in the animal's head the gut expands once more to form the chamber of the buccal cavity. On the floor of this lies the rather small odontophore, deeply cleft on its dorsal side by a longitudinal groove. Over its dorsal and lateral surfaces is spread the radula, looking much like a cuticle raised slightly in a regular pattern, so slight is the development of the teeth. No division into different kinds is possible-indeed it is difficult to recognize the structures as teeth at all. At the posterior end the radula originates in the merest fold of the wall of the gut; it is hardly possible to regard it as a separate radular sac, although it has the correct morphological relationships of such.

The buccal mass contains no cartilages, but is largely composed of connective tissue with deposits of calcium salts and glycogen (Gabe \& Prenant, 1952). Its muscular equipment, too, is much weaker than is usual and amounts to little more than a thin coat of reticulating fibres in its superficial parts. There are no mucous glands here (Fretter, 1937).

The floor and the sides of the buccal cavity are covered with a glandular epithelium and are, in consequence, white in colour. Into the cavity, dorsally, discharge two salivary glands, the histological structure of which has already been described fully by Fretter (I937).

The oesophagus shows no trace of the glandular equipment of a prosobranch, nor of torsion. It is a simple tube, with many parallel folds on its 


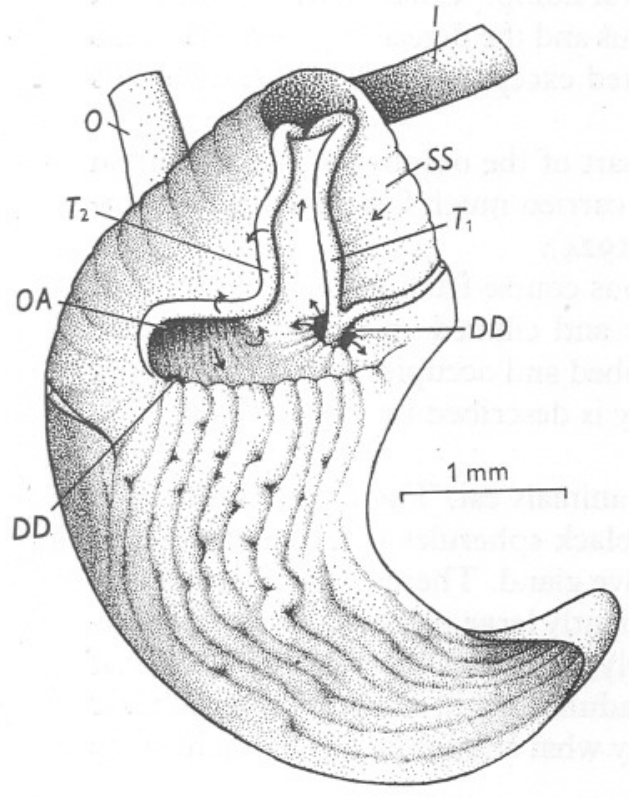

Fig. 5 .

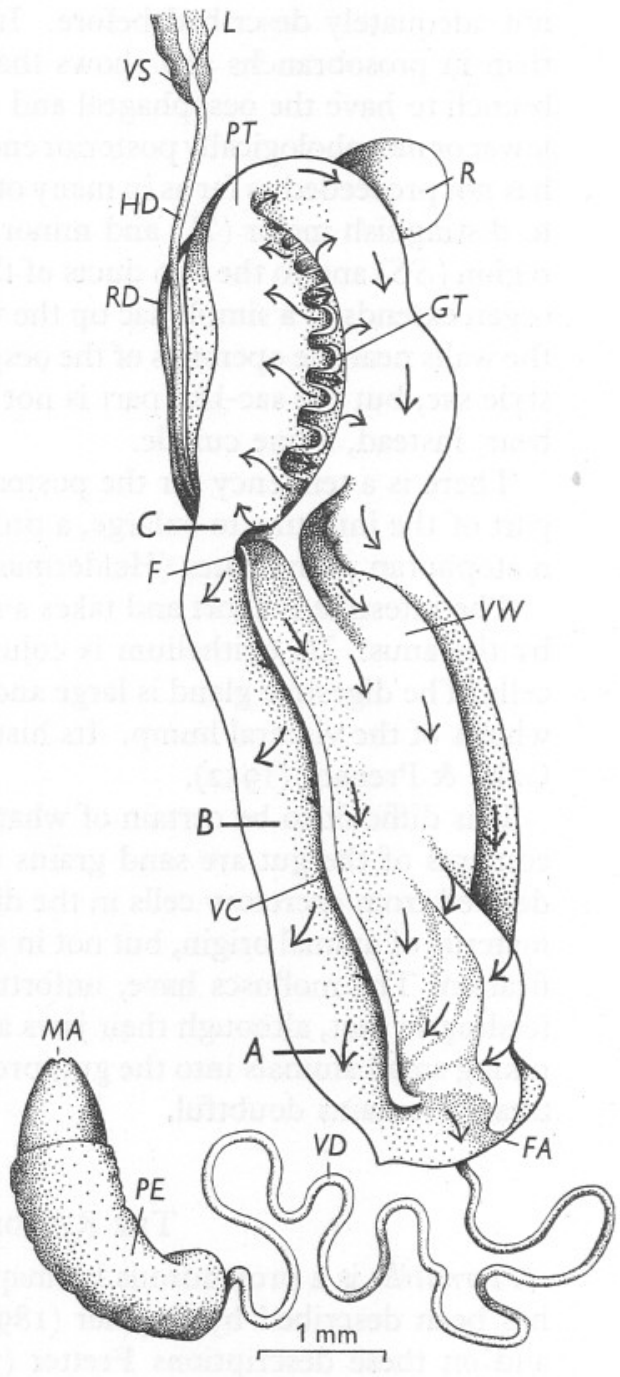

Fig. 6.

Fig. 5. A. tornatilis. Stomach opened dorsally. Arrows show direction of ciliary currents. For explanation of lettering see p. 585 .

Fig. 6. A. tornatilis. The genital ducts. The mucous gland has been opened along its length. Arrows show the direction of ciliary currents. $A, B, C$, mark positions of sections diagrammatically represented in Fig. 7 . 
inner epithelium, which leads back to the stomach (Fig. 5), a part of the gut not adequately described before. It is, like the oesophagus, much simpler than in prosobranchs and shows the characteristic tendency of the opisthobranch to have the oesophageal and intestinal apertures close together at the lower or morphologically posterior end. The process of simplification, however, has not proceeded as far as in many other opisthobranchs and it is still possible to distinguish major $\left(T_{1}\right)$ and minor $\left(T_{2}\right)$ typhlosoles related to the style sac region $(S S)$ and to the two ducts of the digestive gland $(D D)$. The bulk of the organ extends as a simple sac up the visceral hump. Ciliary currents occur on the walls near the openings of the oesphagus and the digestive gland and in the style sac, but the sac-like part is not ciliated except in small strips. The cells bear, instead, a fine cuticle.

There is a tendency for the posterior part of the oesphagus and the initial part of the intestine to enlarge, a process carried much farther in the basommatophoran pulmonates (Heidermanns, 1924).

The intestine is short and takes a sinuous course from left to right to open by the anus. Its epithelium is columnar and ciliated and contains mucous cells. The digestive gland is large and bilobed and occupies most of the upper whorls of the visceral hump. Its histology is described by Fretter (1937) and Gabe \& Prenant (1952).

It is difficult to be certain of what the animals eat. The most conspicuous contents of the gut are sand grains and black spherules of excretory matter derived from excretory cells in the digestive gland. There is also fragmentary material of animal origin, but not in sufficiently large pieces to allow of identification. The molluscs have, unfortunately, not been seen in the process of feeding so that, although their jaws and radula suggest the possibility of their raking small animals into the gut, precisely what animals it is that might so be treated remains doubtful.

\section{The Reproductive System}

A. tornatilis is a protandrous hermaphrodite. The course of the genital ducts has been described by Bouvier (I893), Pelseneer (I893) and Guiart (I90I), and on these descriptions Fretter (I946) has based a comparison with the genital ducts of other gastropods. Pelseneer's figure of the ducts is adopted by Guiart. It shows the little hermaphrodite duct passing forwards from the gonad and joining the duct from a copulatory pouch in which sperms from another individual are stored. The common duct then leads to a large glandular structure associated with the female system, and comprising an albumen gland and a mucous gland. It is stated that on their way through this the outgoing sperm are confined to a gutter between two folds which, near the opening to the mantle cavity, close to form a vas deferens running forwards to the penis. Near the divergence of the vas deferens the female duct opens to the exterior. 
This description may have been put together from a study of dissections (Fig. 6) for when the glandular pallial oviduct is opened by a longitudinal slit, there can be seen a gutter $(V C)$ which leads from near the opening of the little hermaphrodite duct $(H D)$ to the point of origin of the vas deferens $(V D)$. Indeed this channel and the deferent duct appear to be confluent. Sections, however, show that this is not so. The longitudinal gutter, a ciliated and muscular channel, where gland cells are rare, arises anteriorly (without connexion with the vas deferens) near the genital aperture $(F A)$ and leads posteriorly to the duct $(R D)$ of the copulatory pouch or receptaculum seminis $(R)$. It receives this duct, and, immediately beyond this point, opens to a small pouch which is the focal area of the female reproductive system since it also communicates with the hermaphrodite gland and with the albumen gland.

In addition to this connexion the little hermaphrodite duct, which bifurcates at its lower end, connects to a prostate gland $(P)$, the existence of which was not known to Pelseneer, Guiart, or to Gabe \& Prenant (I952). The prostate lies in the same position as the glandular oviduct, for the most part beneath it $(V W)$, the two being so intimately connected that it is difficult to separate them. Anteriorly it is the prostate that narrows to the vas deferens (Figs. 6, 7, $V D$ ) which runs forward to the penis (Fig. 6, $P E$ ) on the right of the head. Thus from the point of bifurcation of the little hermaphrodite duct near its lower end male and female channels are entirely separated.

The structure of the hermaphrodite system may now be followed in greater detail. The description is based on animals which were collected during early September, whilst spawning.

The tubules of the gonad are hermaphrodite, each giving rise to eggs and sperm. The little hermaphrodite duct into which the gonad opens is ciliated throughout its course and has a moderately thick coat of circular and longitudinal muscle fibres. On functional and histological grounds it is divisible into three regions: short proximal and distal parts for conduction only, and an intermediate one which is swollen with unorientated sperm even when eggs are passing to the oviduct. The entrance to this seminal vesicle (Fig. 6, VS) is by way of a muscular papilla, and there is a valve which controls the passage through the duct near the glandular pallial ducts. Dissections of animals which have just spawned show the dilated vesicle as a broad duct, brown in colour, except for a longitudinal streak $(L)$ marking a thin ciliated tract on the wall through which can be seen the iridescence of the underlying sperm. The streak has the same simple ciliated epithelium as the conducting regions of the duct; elsewhere the histology is more complex. Bordering the ciliated tract are gland cells with exceptionally large nuclei and containing protein spherules. The glands are placed between ciliated cells and do not seem to be present in younger animals in which only the male system is mature. Covering a much greater area on the wall opposite the ciliated tract are cells with fine, short 
cilia and vacuolated cytoplasm, the vacuoles containing spherules. The important feature of these cells is that they can ingest spermatozoa; within the cytoplasm ingested gametes lose their identity and are apparently digested. Absorption of effete sperm by the epithelium of the vesicula seminalis has been recorded for Littorina (Linke, I933), the Stenoglossa (Fretter, I94I) and the tectibranch Onchidella celtica (Fretter, 1943). The two branches of the hermaphrodite duct, after its bifurcation into male and female channels, embrace the duct of the receptaculum seminis as it opens to the ventral channel.
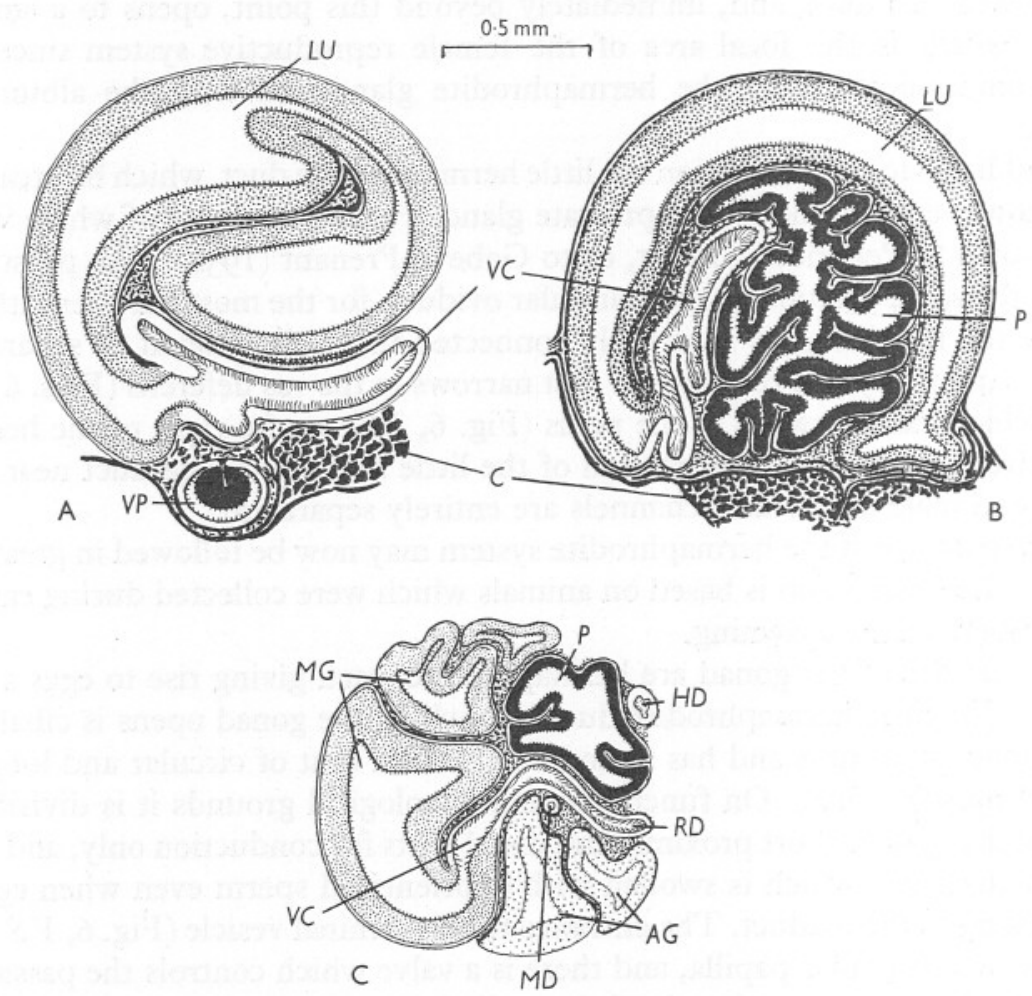

Fig. 7. A. tornatilis. Diagrammatic transverse sections through pallial genital ducts at levels indicated in Fig. 6. For explanation of lettering see p. 585 .

The prostate $(P)$ constitutes the broad pallial region of the male duct. Here the epithelium is thrown into deep longitudinal folds and it has, therefore, a large secreting area. The gland cells are all of one sort, each containing a number of protein spherules, and they alternate with small ciliated cells. This part of the male duct lies immediately above the columellar muscle and under the ventral wall of the oviduct (Figs. 6, 7,VW), to which it is joined by a sheet of connective tissue. Anteriorly, near the origin of the vas deferens, 
the prostate narrows, and its ventral wall becomes a strongly ciliated channel without glands. In this transitional region the typical secreting cells of the upper portion are confined to the dorsal wall where they form a ridge projecting deeply into the lumen $(V P)$. The deferent duct $(V D)$, which passes anteriorly, has the same diameter throughout until it approaches the tip of the penis where it contracts. It is ciliated and not glandular. The penis, which it penetrates, is not invaginable as in other opisthobranchs and is unusually large. When the penis is at rest the duct coils in the haemocoel at its base and in the blood space which lies centrally within it. It is excessively muscular. The tip of the penis forms a glans kept turgid by a core of connective tissue; when the organ is relaxed the tip is slightly sunk into the surrounding tissues which form a shallow fold around it like a prepuce. The vas deferens has a straight course through the connective tissue of the glans.

The female system has characteristic tectibranch features which concern, among other things, the histology of its glands and the relative position of its parts. The gland cells alternate with ciliated cells and are never subepithelial in position. Most of them secrete mucus. The secreting areas of the oviduct comprise two distinct masses: a posterior one $(P T)$ referred to by previous workers as the albumen gland and a larger and more anterior one, the mucous gland. The lumen of the former is complex, that of the latter is a simple channel. The ventral ciliated gutter $(V C)$ is folded off from the secreting epithelium and it is presumably along this that the penis lies to reach the duct of the receptaculum. The penis, when extended, can attain a length which would permit this, and the channel is broad enough to contain it.

The posterior part of the pallial oviduct, the so-called albumen gland, is a composite structure: some of its tubules open into a centrally placed space which almost certainly functions as a fertilization chamber, whereas the remainder communicate with the upper part of the mucous gland since this extends alongside the albumen gland as a straight channel, reduced in size, as far as the posterior end of the oviduct. In sections the true albumen gland can be distinguished from the surrounding mucous tunic on account of the different histological features of the two. The mucous gland has a variety of secreting cells in its epithelium, though the kind which covers most of its surface is the mucous cell filled with uniform spherules. There are, however two places where the gland cells do not produce mucus. These lie along the ventral wall, where they form a narrow strip bordering the ciliated channels and anteriorly, in the epithelium which precedes the genital papilla and spread posteriorly for a short distance along the lateral walls of the gland. The secretion from this anterior end of the mucous gland is more viscid than that produced posteriorly.

Near the genital aperture the glandular epithelium stops rather abruptly, and the ventral channel enlarges to form the small papilla on which the female opening is placed. The epithelium here is ciliated as in the channel. 
The plan of the various parts of the female system suggests that the site of fertilization of the eggs is at the confluence of the albumen and mucous glands. Here is the pouch, already referred to, which receives the female branch of the hermaphrodite duct and also secretion from the albumen gland; it leads directly into that part of the mucous gland into which the receptacular duct opens. It has already been noted by Bouvier (I893) dealing with Acteon solidulus that the receptacular duct may be filled with sperm like the receptaculum itself. In $A$. tornatilis, when spawning, sperm are orientated along the duct, dilating it considerably if they are present in large numbers, but they do not appear to occur in the receptaculum. That pouch is filled with a yellowish brown, viscous fluid, most of which responds to stains for mucus in the same way as secretion from the female tract whilst the other contents stain like prostatic fluid. From these facts it may be deduced that the receptaculum and its duct have a dual function as in the stenoglossans Nucella and Buccinum (Fretter, I94I) where it acts as a storeplace for sperm and, in distally placed outgrowths, for the destruction of superfluous sperm and granules of yolk. There is, however, no obvious absorption in Acteon.

The mouth of the receptaculum and its duct bear a ciliated epithelium; in the pouch, on the other hand, cells with large nuclei and cytoplasm filled with spherules in vacuoles form a columnar epithelium.

The embryos contained in each mass of spawn are individually supplied with albumen and may be seen rotating in this when they have reached the veliger stage. A membrane separates the albumen from the common jelly in which all are embedded, and a more viscid outer layer gives shape to the spawn and forms the cord for attachment. Presumably each egg is fertilized and enclosed in albumen within the fertilization chamber, and is then freed to the general cavity of the mucous gland. Dissection of an animal which is spawning shows that there are large quantities of secretion filling this gland prior to the entry of the eggs, and also shows how the eggs, enclosed in albumen, are forced into this secretion. The spawn mass is retained in the mucous gland until it is complete. The rounded distal end is the first to emerge from the genital aperture, the stalk for attachment leaving last. The glands in the part of the oviduct nearest the mouth produce much of the fluid of which the stalk is composed. The spawn swells when exposed to sea water and superficially resembles that of other tectibranchs such as Haminea and Philine. As in these genera the young of Acteon escape at the veliger stage.

\section{Discussion}

The earliest fossil representatives of Acteon are shells of Acteon (=Cylindrites) acutus (Sow.) from the calcareous portion of the Great Oolite (Bathonian). A. tornatilis does not appear until the Miocene when it occurs in deposits in France, Austria and northern Italy. These may well have been the most 
ancient of opisthobranchs and have had a considerable range in European waters. A century ago Forbes \& Hanley (I853) gave the distribution of A. tornatilis as throughout the British Isles, with a general range from Norway to the Mediterranean. How abundant the animal then was the authors do not say, but our general conception of the distribution of Acteon to-day is that of a rather uncommon animal living in sand at L.W.S.T. and to a depth of sixty or more fathoms, since only very occasional specimens are dredged at Plymouth, Port Erin or Millport. Such infrequent capture, however, may have little meaning since an aquarium known to contain many specimens may exhibit few on account of their burrowing habit; and at Pendine sands the numbers obtained without digging give no idea of their real frequency. They are, in fact, abundant at this spot and presumably in similar habitats throughout Britain.

The habit of burrowing is shared with other opisthobranchs such as Haminea, Scaphander and Philine. As adaptations for this the foot is powerful and the tentacles form lobes round the mouth for shovelling sand away; the cephalic tentacles become flat and spoon-shaped and are used for the same purpose and for blocking the entrance to the mantle cavity, and the eyes sink into the tissues of the head. It may be partly in connexion with this habit, too, that these animals (along with Scaphander and Acera) have evolved the pallial caecum which runs up the spiral of the shell alongside the visceral hump. The most obvious function for such a structure would be to aid respiration, not only by itself providing a respiratory surface, but also by leading a current of water to the neighbourhood of the upper parts of the visceral hump. It may be noted that the gill is small and is built on the usual opisthobranch rather than upon the usual prosobranch pattern. This may well be a less efficient type of gill since in most cases where it occurs the body of the mollusc is naked or only partially covered by shell so that secondary respiratory surfaces are large. Acteon, however, is a type of opisthobranch in which the body may be completely withdrawn into a shell and in which a great deal of the surface of the body is covered even at maximal expansion. In these circumstances accessory respiratory surfaces within, or mechanisms for accelerating the flow of water through, the mantle cavity may be necessary and the caecum may be such a device. In the pyramidellids (Fretter \& Graham, I949), in Omalogyra and Rissoella (Fretter, I948) there is no gill at all, and it is fundamentally the same method which is used in each of these animals to compensate for its absence-longitudinal ridges of ciliated epithelium in the neighbourhood of the hypobranchial gland, which produce a strong exhalant current. These animals, therefore, differ from most molluscs in replacing an inhalant by an exhalant force as the main driving power of their respiratory watercurrent in the mantle cavity. This strong exhalant stream is exploited to some extent in all these animals for the evacuation of excretory matter contained in amoebocytes. These abound in the blood vessels of the pallial caecum in Acteon, from which they escape to the ciliated grooves by diapedesis and are 
swept down to the exhalant siphon. A similar extrusion of blood cells laden with excreta was noted by Fretter \& Graham (I949) in the pyramidellids. It may partly be due to the strength of the current, too, that the anus has retained its primitive position in the innermost part of the mantle cavity instead of extending to near the edge of the mantle skirt. The similarity of these molluscs as regards their production of pallial water currents offers further evidence that pyramidellids and Omalogyra and Rissoella are opisthobranchs.

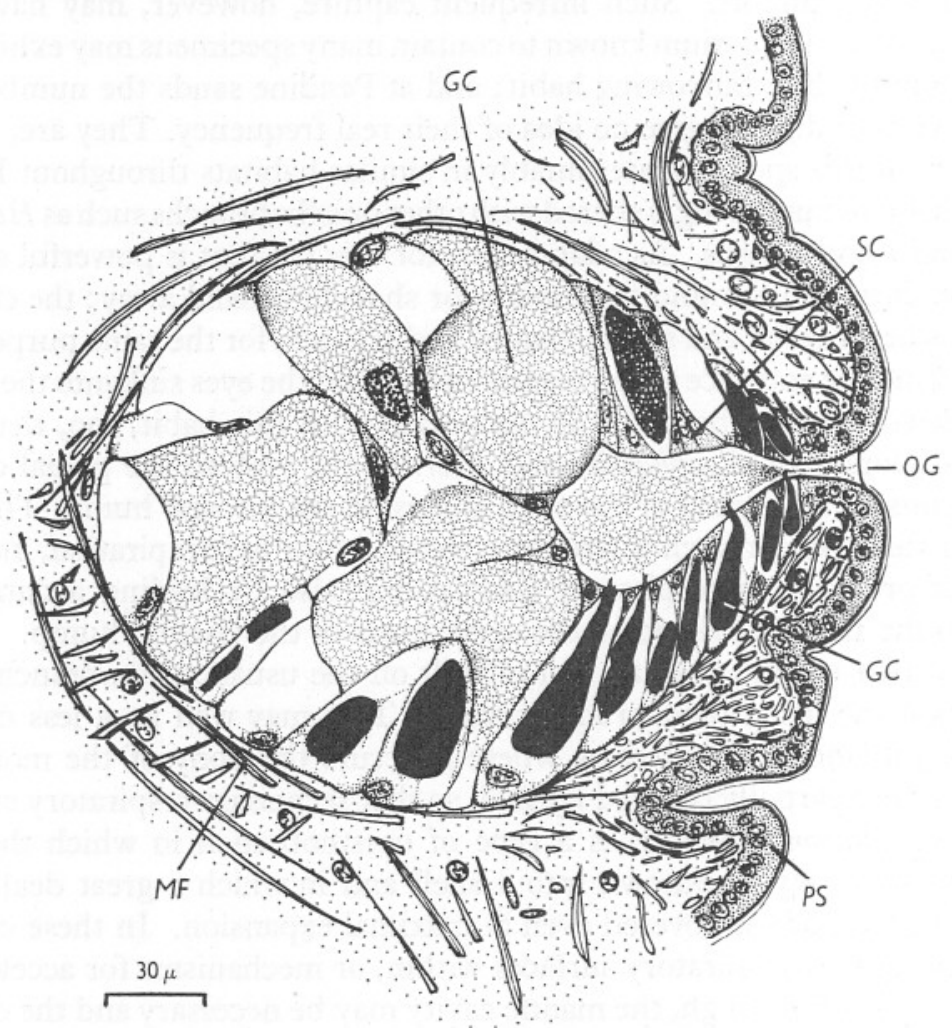

Fig. 8. Siphonaria sp. Vertical section of lateral pedal gland. For explanation of lettering see p. 585 .

Like many opisthobranchs Acteon has a number of special glands associated with the mantle cavity and the mantle itself. When irritated it liberates a purple secretion from the hypobranchial gland and toxic secretions from the repugnatorial glands on the mantle skirt. Glands of almost identical histological nature may be found at the pallial edge or on the sides of the foot of many nudibranchs, opisthobranchs and marine pulmonates. Fig. 8 illustrates such a gland in Siphonaria. Onchidella celtica (Joyeux-Laffuie, I882; von Wissel, 1898; Fretter, 1943) possesses very similar ones except that they discharge by 
nger ducts. Many limpet-like prosobranchs, too, in which the conical shape f the shell and the absence of operculum prevent the animal from shutting up ntirely when disturbed, possess similar or even more elaborate glands. These 1ave been described for Calyptraea and Crepidula by Graham (1954), but perhaps the most complex arrangement is to be met in Patelloida virginea. If the mantle edge of this animal be examined it will be found to be thickly set with a series of unicellular glands round its entire length (Fig. 9). The margin of the mantle also carries, at regular intervals, groups of special cells carrying

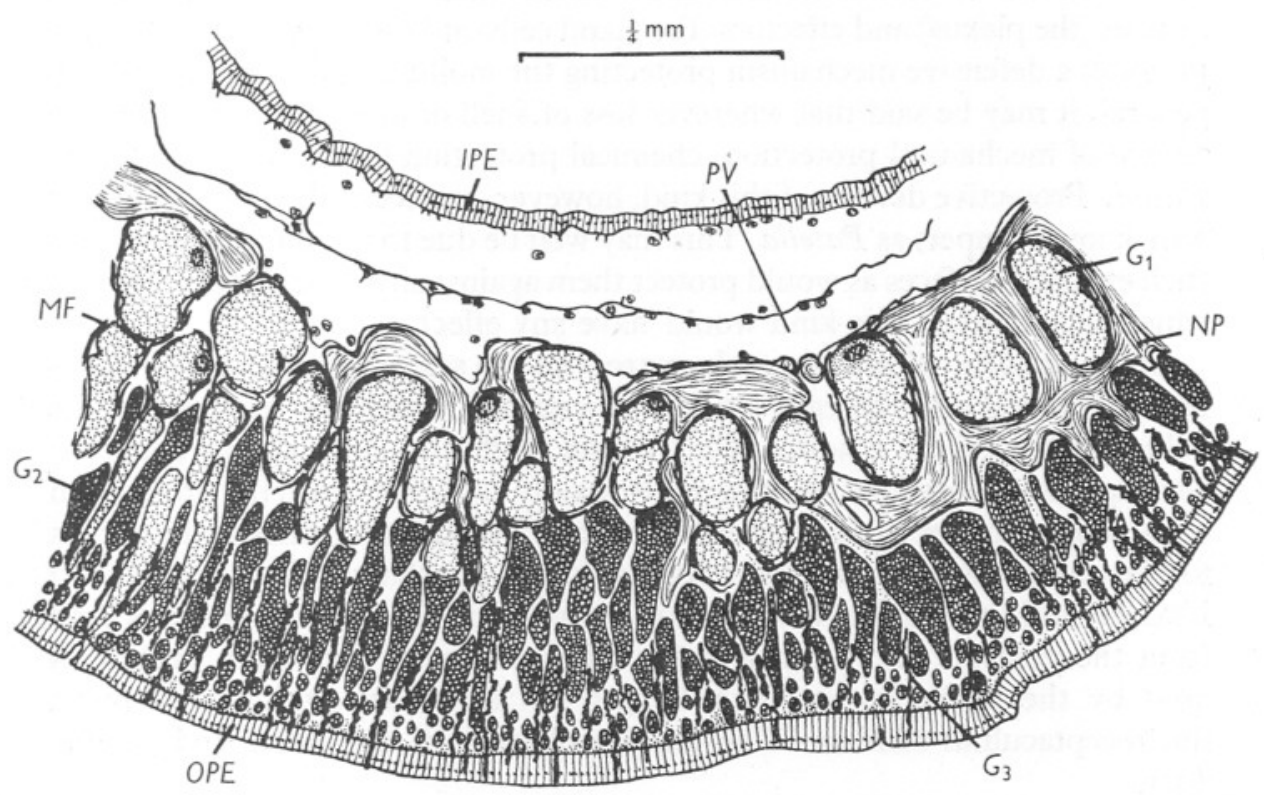

Fig. 9. Patelloida virginea. Tangential section of part of edge of the mantle skirt showing the nerve plexus, gland cells and muscle fibres around gland cells. The sensory organs on the outer pallial epithelium do not occur at this level. For explanation of lettering see p. $5^{85}$.

long, motionless cilia set on slight projections. Even when the mollusc is closely pressed to the underlying rock these ciliated structures project a little beyond the edge of the shell. There are three types of gland cell. The first, the most conspicuous and the commonest, is a flask-shaped gland, bright white in colour, the body of the flask set deep in the pallial tissue and communicating with the edge by a long duct. The body of each of these cells is surrounded by a basketwork of muscle fibres and the cytoplasm is granular. On contraction of the muscles threads of white secretion are squeezed into the water where they retain their identity for some time. Exactly similar secretion comes from the glands in Acteon, Onchidella and the calyptraeids, and experiment by one of us (V.F.) has shown that this is rapidly toxic to small animals. 
The two other types of gland in Patelloida lie in banks successively nearer the mantle edge and they have correspondingly shorter ducts. The second is also a large, pear-shaped gland, but it lacks the muscular coat of the first type, its cytoplasm is homogeneous and uncoloured and its secretion appears to disperse. The third type is a bright red in a living mollusc and the gland is short and tubular. All these glands, but the first type in particular, are surrounded by a great plexus of nerves connected to the main pallial nerve, which also involves the groups of sensory cilia set on the mantle edge. It seems likely that here is a local arrangement of sense organs (the ciliated cells), nerve centres (the plexus) and effectors (the gland cells and their muscle coat) which provides a defensive mechanism protecting the mollusc against predators. In general, it may be said that wherever loss of shell or operculum deprives the animal of mechanical protection, chemical protection has appeared as a substitute. Protective devices of this kind, however, are noticeably absent in such well-known limpets as Patella. This may well be due to their ability to live on such exposed surfaces as would protect them against any potential predator on which secretions of this kind would have any effect.

In the majority of prosobranch gastropods the sexes are separate, fertilization is internal and the eggs are laid in capsules which are secreted by the pallial region of the oviduct. This region traffics in both sperm and ova: although its elaborations are apparently mainly concerned with the production of secretions for capsules, they also comprise well-defined tracts and pouches for the manipulation of sperm received during copulation. In Littorina and Nucella, and in other genera, the bursa copulatrix receives the seminal fluid from the penis of the partner and a ciliated groove, free from glands, is used by the sperm to travel the length of the pallial oviduct and reach the receptaculum seminis. The receptaculum is at the inner end of this duct.

In the opisthobranchs hermaphroditism is the rule. A hermaphrodite gland replaces the unisexual gonad, and the ducts which pass its products to the exterior must deal with outgoing as well as incoming spermatozoa, and produce the gelatinous secretions which characterize the spawn. In detorted gastropods, both pulmonates and opisthobranchs, the pallial duct has separated from the body-wall which restricted its further evolution in the prosobranchs and, freed to the haemocoel, it attains a further degree of complexity and a relatively larger size. The tectibranch Acteon tornatilis is an exception. Although it has an assemblage of opisthobranch characters which include hermaphroditism, its genital ducts are still linked to the musculature of the body-wall and have a straight course from gonad to genital aperture. In some tectibranchs such as Philine, Scaphander (Lloyd, 1952) and Aplysia (Eales, I92I) the plan of the hermaphrodite duct is similar to that of the female prosobranch in that it is single from gonad to genital aperture, and is simply divided by longitudinal ridges into sperm-conducting and egg-conducting 
grooves; whilst the groove which conducts sperm to the exterior passes forwards from the female opening to the penis on the right side of the head, giving an open vas deferens-a condition which may be primitive for the prosobranchs (Fretter, I946) as well as the opisthobranchs. Acteon is not primitive in this respect since from its origin at the distal end of the gonadial duct the vas deferens is closed, and, throughout its course, is separated from the oviduct. The vas deferens leads to the penis which is, of course, unaffected by detorsion. In Acteon the mantle cavity is large and, as in prosobranchs, offers protection to the penis, whereas in other tectibranchs with a reduced mantle cavity, the penis, when not in use, lies retracted in a sheath sunk into the haemocoel.

Perhaps it is on account of the separation of pallial vas deferens and oviduct, and the possession of a penis of exceptional size, that the arrangement of sperm pouches in the female tract of Acteon differs from that of Philine and Scaphander in which the prosobranch plan is adhered to. In these two genera the homologue of the bursa copulatrix of prosobranchs is not far from the female opening, and is characterized by the possession of a long, muscular duct and pigmented contents of the pouch. If copulation be reciprocal the insertion of the penis into the duct, which receives the seminal fluid, would not block the passage of the hermaphrodite tract nor interfere with the flow of spermatozoa to the recipient's own penis. A deeper insertion of the penis to the vicinity of the receptaculum might well do so, however. Now in Acteon male and female tracts are separate ducts and the penis is long enough to extend to the inner end of the pallial oviduct: a bursa near the female opening is not developed and it is assumed that the penis uses the ventral channel of the oviduct to deposit sperm in the duct of the receptaculum, where they may be found orientated soon after copulation. In structure and in function the receptaculum resembles the bursa and not the receptaculum of Philine and Scaphander - the duct long and muscular, the pouch spherical and conspicuous on account of its size and pigmented contents. These comprise prostatic fluid received during copulation and sometimes other secretions from the genital ducts. Secretion is apparently also produced by the epithelium of the pouch itself: this may agglutinate the debris or cause the breakdown of the proteins (Lloyd, I952). The ultimate fate of the contents is unknown: it may be that they are passed into the surrounding haemocoel and so utilized by the animal. A receptaculum and a bursa (the spermatheca of Eales) are developed in Aplysia, the former receiving sperm directly from the penis, the latter accumulating unwanted material introduced with the sperm and perhaps absorbing it or discharging it to the exterior (Eales, I92I).

As in other tectibranchs like Onchidella (Fretter, I943), Aplysia (Eales, I92I), Philine and Scaphander (Lloyd, I952) the albumen gland is an appendage of the female tract: this contrasts with prosobranchs where the eggs traverse the cavity of the gland. 
In a comparison between the genital ducts of prosobranchs and opisthobranchs Fretter (1946) regarded the arrangements of the ducts in Acteon as showing remarkable agreement with those of the female Littorina and the Stenoglossa. The comparison was based on Guiart's (I90I) description of Acteon tornatilis in which the prostatic region of the vas deferens underneath the pallial oviduct was not mentioned and the ventral channel of the oviduct was regarded as the vas deferens. Now that another investigation of that species has been made it appears that the reproductive system displays a mixture of primitive and advanced characters. The former, which are shared with the prosobranchs, relate to the large and uninvaginable penis and the association of the pallial ducts with the body-wall. The latter concern the loss of the large hermaphrodite duct with the separation of male and female channels, a character which is unusual in the tectibranchs, though found in higher opisthobranchs.

The alimentary tract shows, in general, an apparent simplicity, even the radular structure having a superficial suggestion of extreme primitiveness. When, however, the gut is compared with that of a prosobranch the loss of all trace of oesophageal glands, of all signs of torsion, the complex histology of the salivary and digestive glands and the modification of the stomach indicate that the simplicity must be secondary and the radular structure advanced in relation to a (presumably) carnivorous way of life. The position of the anus is, in fact, the sole genuinely primitive character which the gut appears to possess, and there is no very obvious reason why that might not also be secondary.

Acteon, therefore, is a gastropod with a medley of prosobranch and opisthobranch characters. The external facies is chiefly prosobranch, with its emphasis on shell and operculum, its large mantle cavity still facing well forward and the uninvaginable penis. Apart from the gill, which is opisthobranch in organization, the main departures from the usual prosobranch appearance might well be directly due to adaptation for burrowing.

So far as internal anatomy is concerned the nervous system, with its streptoneury and lack of fusion of ganglia, is frankly prosobranch in plan; and so is the auricle lying anterior to the ventricle. The reproductive system, on the other hand, shows a mixture of characters and the gut is distinctly advanced.

Acteon and the Acteonidae, in view of this mixture of characters, must always occupy a debatable position in any clear-cut classification. There is, however, a gentler passage, with animals showing more intermediate patterns of structure, from Acteon to the more characteristic opisthobranchs than from Acteon to the more characteristic prosobranchs. As a matter of convenience, therefore, it seems appropriate to leave the animal where it has long been placed, as the most primitive type of living opisthobranch. This work on Acteon, and recent work on Siphonaria (Hubendick, 1947), on the ellobiid pulmonates (Morton, I954), on Onchidella (Fretter, I946), on Omalogyra and Rissoella (Fretter, I948), on the pyramidellids (Fretter \& Graham, I949) and 
on other tectibranchs (Lloyd, I952), demonstrate, however, with great emphasis, how close the relationship of all the three major groups of gastropods is at some central point such as this. It seems likely that further research will show that it is from some archaeogastropod nucleus, represented to-day by such molluscs as the trochids, that all these groups have arisen.

This work was carried out at the Plymouth Laboratory of the Marine Biological Association. Our thanks are due to Birkbeck College for a grant towards the cost of publication.

\section{SUMMARY}

Acteon tornatilis is an opisthobranch mollusc which burrows in sand, using foot, labial and cephalic tentacles in the process. The last also help to exclude sand from the mantle cavity, which is extended into a caecum coiling alongside the visceral hump, presumably used for respiration but also for excretion. The main pallial water current is an exhalant one on the right.

The mantle skirt carries, on the left, numerous repugnatorial glands with toxic secretions.

Labial glands lie at the mouth and the buccal cavity contains jaws and a reduced buccal mass and radula. Into it open salivary glands the structure of which is like that of the pyramidellids. The oesophagus shows traces neither of glands nor of torsion whereas the stomach, though simplified, has resemblances to that of a prosobranch.

The reproductive system is shown to be different from previous descriptions. Male and female ducts are separate from the lower end of the little hermaphrodite duct. The former passes to a prostate from which a vas deferens leads to a large uninvaginable penis; the latter has associated albumen and mucous glands and there is a receptaculum seminis to the duct of which a ventral channel leads from the female aperture in the mantle cavity.

Discussion of these aspects of the animal's structure confirms its position as the most primitive of the opisthobranchs.

\section{REFERENCES}

Bouvier, E. L., I893. Sur l'organisation des Actéons. C.R. Soc. Biol., Paris, T. 5, pp. 25-30.

Eales, N. B., I921. Aplysia. L.M.B.C. Memoir xxiv, 84 pp. Liverpool: University Press.

Forbes, E. \& Hanley, S., I853. A History of British Mollusca and their Shells. London: van Voorst.

FRETTER, V., 1937. The structure and function of the alimentary canal of some tectibranch molluscs, with a note on excretion. Trans. Roy. Soc. Edinb., Vol. 59, pp. 599-646.

I94I. The genital ducts of some British stenoglossan prosobranchs. F. Mar. biol. Ass. U.K., Vol. 25, pp. 173-2II. 
FRETTER, V., I943. Studies in the functional morphology and embryology of Onchidella celtica. (Forbes \& Hanley) and their bearing on its relationships. F. Mar. biol. Ass. U.K., Vol. 25, pp. 685-720.

- 1946. The genital ducts of Theodoxus, Lamellaria and Trivia, and a discussion on their evolution in the prosobranchs. F. Mar. biol. Ass. U.K., Vol. 26, pp. 312-5I. I948. The structure and life-history of some minute prosobranchs of rock pools: Skeneopsis planorbis (Fabricius), Omalogyra atomus (Philippi), Rissoella diaphana (Alder) and Rissoella opalina (Jeffreys). F. Mar. biol. Ass. U.K., Vol. 27, pp. 597632.

FretTer, V. \& Graham,A., 1949. The structure and mode of life of the Pyramidellidae, parasitic opisthobranchs. F. Mar. biol. Ass. U.K., Vol. 28, pp. 493-532.

Gabe, M. \& PRENANT, M., I952. Quelques particularités histologiques d'Acteon tornatilis L. Bull. Soc. zool. Fr., T. 77, pp. 220-8.

Gabe, M. \& Prenant, M., I953. Données morphologiques sur la région antérieure du tube digestif d'Acteon tornatilis L. Bull. Soc. zool. Fr., T. 78, pp. 36-44.

Graham, A., I954. The anatomy of the prosobranch Trichotropis borealis Broderip \& Sowerby, and the systematic position of the Capulidae. F. Mar. biol. Ass. U.K., Vol. 33, pp. 129-44.

GuIART, J., I90I. Contribution à l'étude des gastéropodes opisthobranches et en particulier des céphalaspides. Mém. Soc. zool. Fr., T. 14, pp. 5-219.

HeIDERMANNS, C., I924. Über den Muskelmagen der Süsswasserlungenschnecken. Zool. Fb. Physiol., Bd. 4I, pp. 335-424.

HuBENDICK, B., 1947. Phylogenie und Tiergeographie der Siphonariidae. Zur Kenntnis der Phylogenie in der Ordnung Basommatophora und des Ursprungs der Pulmonatengruppe. Zool. Bidr. Uppsala, Bd. 24, pp. I-2I6.

JoyeUX-LAfFuIE, J., I882. Organisation et développement de l'oncidie Oncidium celticum Cuv. Arch. Zool. exp. gén., T. I0, pp. 225-383.

LINKE, O., I933. Morphologie und Physiologie des Genitalapparates der Nordseelittorinen. Wiss. Meeresuntersuch. Abt. Helgoland (N.F.), Bd. I9, No. 5, 60 pp.

LLOYD, H. M., I952. A study of the reproductive systems of some opisthobranchiate molluscs. Ph.D. thesis, University of London.

Morton, J. E., I954. The evolution of the Ellobiidae, with a discussion on the origin of pulmonates. Proc. zool. Soc. Lond. (in press).

Pelseneer, P., I893. Sur le genre Actaeon. Ann. Soc. roy. malacol. Belg., T. 28, 3 pp.

- 1894. Recherches sur divers opisthobranches. Mém. Sav. étr. Acad. R. Belg., T. $53, \mathrm{I} 57 \mathrm{pp}$.

PERrIer, R. \& FIsCHER, H., I9II. Recherches anatomiques et histologiques sur la cavité palléale et ses dépendances chez les Bulléens. Ann. Sci. nat. Zool., gth ser., T. I4, pp. I-189.

SARS, G. O., I878. Bidrag til Kundskaben om Norges Arktiske Fauna. I. Mollusca regionis arcticae Norvegiae. Christiania.

Wissel, K. voN, I898. Beitrage zur Anatomie der Gattung Oncidiella. Zool. fb., Suppl. 4, pp. 583-640. 


\section{ABbreviations USED IN THE FigURES}

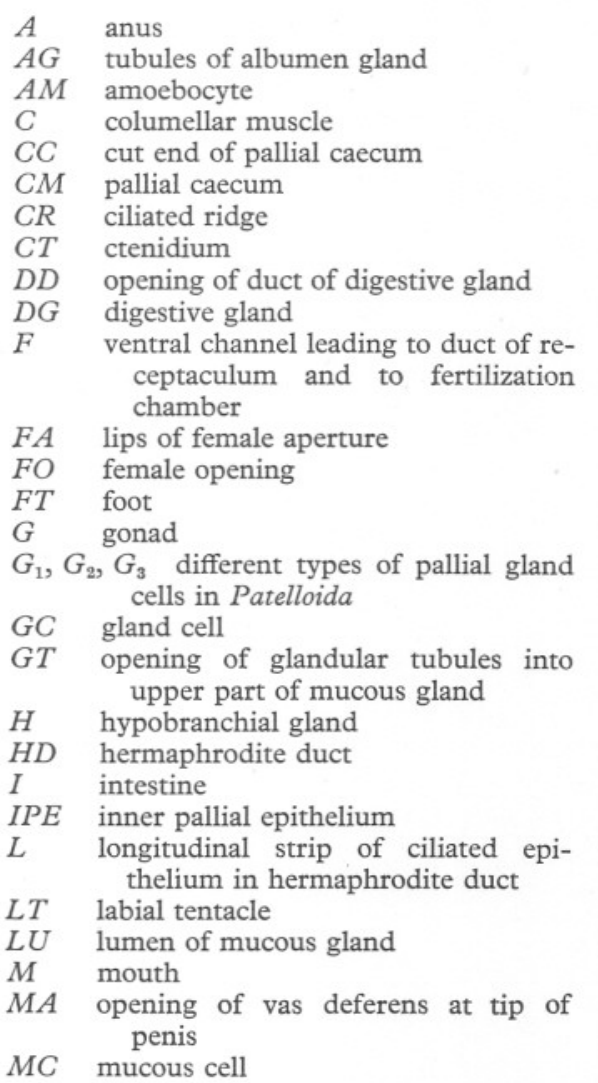

$M D$ male deferent channel, a bifurcation of $M F$ muscle fibre

$M G$ tubules of mucous gland

NP nerve plexus

$O$ oesophagus

$O A$ oesophageal aperture

$O G$ opening of repugnatorial gland

$O P E$ outer pallial epithelium

$P \quad$ prostate gland

$P E$ penis

$P G$ pallial genital duct

$P S$ pedal surface

PT posterior part of pallial oviduct formed of albumen gland and tubules of mucous gland

$P V \quad$ pallial vein

$R \quad$ receptaculum seminis

$R D$ duct of receptaculum seminis

$R G \quad$ repugnatorial gland

$S$ exhalant siphon

$S C \quad$ supporting cell

$S S \quad$ style sac region of stomach

ST stomach

$T \quad$ cephalic tentacle

$\mathrm{T}_{1}, T_{2}$, major and minor typhlosoles

$V$ blood space of caecum

$V C$ ventral channel

$V D$ vas deferens

VP vas deferens with prostatic gland cells projecting from the dorsal wall

$V S$ vesicula seminalis

$V W$ ventral wall of mucous gland overlying prostate 